\title{
Hunting efficiency of Red-footed Falcons in different habitats
}

\author{
Péter Palatitz ${ }^{1 *}$, Szabolcs Solt ${ }^{1}$, Éva Horváth $^{1}$ \& \\ LÁSZLÓ KOTYMÁN ${ }^{2}$
}

Péter Palatitz, Szabolcs Solt, Éva Horváth \& László Kotymán 2015. Hunting efficiency of Red-footed Falcons in different habitats. - Ornis Hungarica 23(1): 32-47.

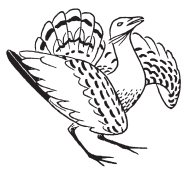

Abstract We studied hunting success of 13 male Red-footed Falcons by radio-telemetry in the second phase of chick rearing. We coded 484 hunting events, and the success measured in captured prey biomass/minute was exceedingly high in corn fields. This is mainly caused by the fact that the effectiveness of hunting for vertebrate prey was high on the harvested stubble fields. Moreover the observed falcons hunted for insects in these stubble field and alfalfa fields most successfully. In the studied habitat the chick feeding period of Red-footed Falcons coincide with the harvest of cereal fields, and the suddenly created lower vegetation cover increases temporarily the accessibility of prey items.

Till they were available and could be efficiently harvested, the falcons hunted on the fields within a $1 \mathrm{~km}$ radius from the nesting colony for the more profitable vertebrate prey. Thereafter they searched for vertebrate prey on the fields located at average 1-2.5 km distance from the colony. In the later zone falcons started to hunt insects, too, but approximately third of the captured insects $(36.4 \%)$ was consumed immediately and was not delivered to the colony. Conversely larger prey was almost always (98.1\%) carried directly to the nest site. Only one part of the Field Voles was observed to be eaten regularly: the brain. Finally later in the breeding season falcons were observed more and more often to hunt in the nearest fields again, this time for insects. Probably due to the depletion of the distant plots, the closer fields with lower investment became a competitive alternative for the birds.

Our results highlight the fact that even for such characteristic short-grass specialist birds as Red-footed Falcons the prey sources offered by arable lands might be temporarily exploited with success. Hence it is very important to integrate the measures offered by agri-environment schemes into the management of this threatened species.

Keywords: radio-telemetry, habitat use, resource utilization, Falco vespertinus, agro-environmental scheme

Összefoglalás A fiókanevelési időszak második felében követéses rádiótelemetriával vizsgáltuk 13 kék vércse hím vadászati sikerét. Összesen 484 vadászatot kódoltunk le, a vadászati sikert az átlagosan 1 perc alatt zsákmányolt biomasszában (g) mértük. A vizsgált egyedek vadászati sikere kiemelkedő volt a kalászos kultúrákban. A gerinces préda zsákmányolási hatékonysága magas volt a gabonatarlókon, de rovarokra emellett lucernatáblákon is sikeresen vadásztak. Ennek oka lehetett, hogy a vércsék fiókanevelése egybeesett a kalászosok betakarítási időszakával, amikor a növényzeti borítás megszünése a madarak táplálékául szolgáló fajok elérhetöségét időszakosan megnövelte.

Ameddig eredményesen kiaknázhatóak voltak, a kék vércsék a fészektelep körüli, 1 kilométernél közelebbi táplálkozó területeken nagyobb profittal megszerezhető gerinces prédát zsákmányolták. Ezt követően az átlagos távolságú (1-2,5 km közötti) táblákon keresték a gerinces zsákmányolás lehetőségét. Ha ilyen távolságba eltávolodtak a fészkeiktől, már rovarokat is zsákmányoltak, de ezek mintegy harmadát $(36,4 \%)$ saját maguk fogyasztották el. Ellenben a mezei pockoknak csak az agyvelejét ették meg, a többit szinte minden esetben a fészekhez vitték $(98,1 \%)$. Mivel vélhetően a távoli $(>2,5 \mathrm{~km})$ zónában való táplálékkeresés és vadászat költsége legfeljebb gerinces zsákmányolás esetén térül meg a madaraknak, a költés végéhez közeledve egyre gyakrabban jelentettek versenyképes alternatívát a legközelebbi területeken megfigyelt rovarvadászatok.

Eredményeink felhívják a figyelmet arra, hogy még egy olyan tipikusan pusztai fajnak tartott ragadozó madár, mint a kék vércse, időszakosan hatékonyan aknázhatja ki a mezőgazdasági élőhelyek kínálta forrásokat. Fontos ezért, hogy a faj természetvédelmi kezelésébe bevonjuk az agrár-környezetvédelem nyújtotta eszköztárat is.

Kulcsszavak: rádió-telemetria, élőhelyhasználat, forráshasználat, Falco vespertinus, agrár-környezetvédelmi támogatás 
${ }^{1}$ Red-footed Falcon Conservation Working Group, MME/BirdLife Hungary, 1121 Budapest, Költö utca 21., Hungary, www.falcoproject.eu

${ }^{2}$ Körös-Maros National Park Directorate, 5540 Szarvas, Anna liget 1., Hungary

*corresponding author: palatitz.peter@mme.hu

\section{Introduction}

Red-footed Falcons (Falco vespertinus) are gregarious in all phases of their life cycle from breeding to migration. Single bids and flocks can be observed throughout the whole year regardless of the age group or sex of the bird. The composition of these groups, the role of individuals in searching for food, or the true complexity of hunting behaviour are all not yet discovered in this species. In other communal feeding bird species (Wright et al. 2003, Weimerskirch et al. 2010), information exchange (Ward \& Zahavi 1973), recruiting function (Richner \& Heeb 1996) and the joint exploitation of food resources (Krebs et al. 1972) are supposed to be the most probable reasons to form groups. We have very scarce knowledge on the time and space pattern of hunting of aggregated individuals, and the factors influencing this phenomenon in most of the bird species.

The Red-footed Falcon is considered a generalist predator (Cramp \& Simmons 1980). Dietary analyses are based on observations of nestling prey provisioning or the analysis of non-digested parts of the prey remains. In the Carpathian Basin Red-footed Falcons feed their chicks predominantly with insects (Insecta) (Keve \& Szijj 1957): mainly larger representatives of the following orders: Orthoptera, Coleoptera and Odonata. Falcons can practically snatch any insect either from the air, surface of vegetation or from the ground (Haraszthy et al. 1994, Purger 1998). There might be as many as $30-100$ insect species in the diet, and even the small 5-10 mm sized arthropods are regularly caught by the Falcons. On a typical steppe grassland with short vegetation cover as the Hortobágy, the following species were most often preyed upon: Elaphrus riparius, Calliptamus italicus, Decticus verrucivorus, Harpalus affinis, Gryllotalpa gryllotalpa, Zabrus tenebrioides, Geotrupes mutator and Amara aenea (Haraszthy et al. 1994). At some habitats the following vertebrate animals can also be important, especially when they are superabundant in gradation years: Common Spade-foot Toads (Pelobates fuscus) (Horváth 1963) and some small rodent species, especially the Field Vole (Microtus arvalis) (Keve \& Szijj 1957, Haraszthy et al. 1994). Besides the above mentioned species lizards (Lacerta sp.) and sometimes small passerines (e.g. Sylvia sp., Alauda sp.) are also captured by Red-footed Falcons (Fülöp \& Szlivka 1988).

Red-footed Falcons have two distinct foraging tactics: active hunting and perch hunting. In the former the bird catches large insects in flight, or it might hover with fast wing-beats above a spot, and then swoops down on the prey. Perch hunting is performed from various elevated observation posts: from the ground, vegetation, pylons or wires of power lines. The bird sits on these objects, and waits until a prey item passes by near enough to launch a successful attack either with a short glide or some powerful wing-beats.

Red-footed Falcons prefer grassy habitats for nesting (Haraszthy et al. 1994), colonies are often found in the near vicinity of grazed 
pastures (Purger 1996). The current breeding distribution of the species in Hungary negatively correlates with the ratio of forest cover within a $3 \mathrm{~km}$ radius circle around the colony (Fehérvári et al. 2009). The artificial nesting colonies that harbour more than two thirds of the Hungarian population (Palatitz et al. 2010) were assigned to areas where larger natural or semi-natural grasslands are present (Fehérvári et al. 2012). Regular breeding pairs in some places of the Hungarian extensive agricultural landscape show that in some extent birds can tolerate the lack of natural grassland habitats. There are reports from the Bachka Region/Serbia on Red-footed Falcon colonies that existed for decades surrounded almost exclusively with arable lands (Fülöp \& Szlivka 1988).

Resource utilisation of the species is not yet described in the scientific literature, only some indirect assumptions are listed. Observations carried out on the Hortobágy suggest that Red-footed Falcons hunted in the close vicinity of their colonies on grasslands, catching Orthopterans, in wet year Common Spade-foot Toads while in dry years Field Voles were carried in large quantities to the nest (Haraszthy et al. 1994). In the literature and species descriptions diverse natural and agricultural habitats are listed, where Red-footed Falcons hunt successfully (Haraszthy et al. 1994, Purger 1997, Haraszthy 1998). The studied radio-tagged individuals clearly avoided dense, closed woody vegetation patches. These individuals most often visited grasslands, but neither these, nor the also frequently visited alfalfa fields were preferred positively compared to the availability of the habitat types within the homerange. Despite low sample sizes two groups of birds could be clearly distinguished in our previous analysis: the members of the first group visited mainly alfalfa fields be- sides grasslands while the other choose cereal fields besides grasslands (Palatitz et al. 2011).

In this work we analyse the same dataset (Palatitz et al. 2011) and try to find the reasons for the individual fine-scale hunting habitat choice and describe temporal and spatial pattern of the hunting of Red-footed Falcons in the chick rearing phase of nesting.

\section{Methods}

The field work was carried out in the Kardoskúti Fehértó region of the Körös-Maros National Park Directorate (KMNPI) at the Red-footed Falcon study area between 2006-2008 (Fehérvári et al. 2008). We used the digital map with reference to individual arable land plots, that enabled us to individually recognise each plot (Kristóf et al. 2007, Palatitz 2012). This typical Great Plain habitat, containing high percent of seminatural grassland housed three artificial nestbox colonies, where in the study years 55-95 pairs of Red-footed Falcons bred (Kotymán et al. 2015).

We captured adult birds according to the permit of the Nature Protection Authorities: after the eggs hatched the adults were captured near the nest using decoy birds and mist nets (Bub 1991). During the study 40 birds were tagged with 3.5 gr miniature radio-transmitters attached to tail feathers, which were tracked from the ground with receivers. We used the radio-tracking data to describe the hunting of Red-footed Falcons by following the tagged individuals (Palatitz et al. 2011).

The term 'hunt' was used to describe the behaviour elements in a field to find and capture prey. The duration and pattern of the hunts of females were considerably dif- 
ferent form that of males' (Palatitz et al. 2015), probably due to the different roles of the sexes during nesting. The majority of food provisioned to the chicks was carried to the nests by the males. Therefore we only analysed the hunts of male individuals. In order to avoid bias only those hunts were entered into the analyses, where the entire length of the hunt was coded (from entering the actual plot till leaving). Previous analyses clearly indicated that the time spent with hunting in a given study plot was dependent first of all on the applied hunting technique (active versus perch hunting). We assume not only the average length (time allocation), but also the energy gain per time unit also varies according to the hunting technique. Active hunting involving hovering requires significant amount of muscle work. On the other hand the energy requirement of perch hunting is much lower (Masman \& Klaasen 1987, Pennycuick 2008). Therefore we only analyse in this study the active hunts. Each data form gave information whether the hunt was successful or unsuccessful, or whether the observer was uncertain. If possible we also took note of the prey with the best possible taxonomic resolution (most often we could only distinguish vertebrate and invertebrate prey). We also recorded whether the prey item was consumed, or the bird left the study plot with the prey (Palatitz 2012).

Hunting success was measured as the biomass of prey gained per time unit. To estimate the biomass of invertebrate and vertebrate prey we used our own measurements based on live (wet) weight of the prey taxa from similar habitats. As the standard deviation of the two main prey category (insects and voles) were quite large, we gave a value of 20 to vertebrate prey and a value of 1 to insect prey in order to avoid overestimat- ing the significance of vertebrate prey items (Palatitz 2012). The dependent variable of hunting success was formed as the potentially available prey biomass per time unit $=(\log ($ prey total weight $[$ grams $] /$ duration of hunt [minute]).

To analyse the success of hunts we used decision trees (Breiman et al. 1984). We studied the effect of the following potentially effective grouping variables: hunting location (code of the arable field), individual, nesting location, nesting type (solitary vs. colonial), hunting strategy (=cereal or alfalfa (see in detail Palatitz et al. 2011), habitat type (grassland, cereal, alfalfa, intertilled crops) and Julian date.

Based on the distance of the hunt from the nest we assigned all hunting events by cluster analyses into three natural categories: 1 (near) distance $<1 \mathrm{~km} ; 2$ (average) distance: $1-2.5 \mathrm{kms}$ and finally 3 (distant) $2.5-$ $5 \mathrm{kms}$ (Palatitz 2012).

QGIS 1.7.3 'Wroclaw' (Quantum GIS Development Team 2011) and R 2.13.1 software were used to carry up the analyses (Calenge 2006, R Development Core Team 2011).

\section{Results}

We succeeded to code altogether 484 active hunts in full length of 13 male Red-footed Falcons. When the outcome of the hunt was known, 223 proved to be successful (48.3\%) and 239 unsuccessful $(51.7 \%)$. Their distribution by habitat type is given in Table 1 .

We could assign prey category and biomass estimate to 190 hunting events. Our analysis distinguished two significantly different $(\mathrm{p}=0.008)$ groups of huntings (Figure 1). While in cereal fields $(n=88)$ the average of biomass per unit time (grams/minute) is 


\begin{tabular}{|l|c|c|c|c|c|}
\hline \multirow{2}{*}{ Observed active hunts } & \multirow{2}{*}{ Total } & \multicolumn{4}{|c|}{ Habitat type } \\
\cline { 3 - 6 } & & $\begin{array}{c}\text { Grass } \\
\text { land }\end{array}$ & $\begin{array}{c}\text { Cereal } \\
\text { stubble }\end{array}$ & $\begin{array}{c}\text { Inter } \\
\text { tilled crops }\end{array}$ & Alfalfa fields \\
\hline The ratio of all hunts & 484 & $41.3 \%$ & $43.6 \%$ & $4.3 \%$ & $10.7 \%$ \\
\hline $\begin{array}{l}\text { The ratio of successful } \\
\text { hunts }\end{array}$ & 223 & $44.4 \%$ & $45.3 \%$ & $1.8 \%$ & $8.5 \%$ \\
\hline Success rate* & & $51.8 \%$ & $50.0 \%$ & $19.0 \%$ & $39.6 \%$ \\
\hline
\end{tabular}

* number of successful hunts/number of total hunts

Table 1. The distribution of active hunts and estimated hunting success rate of Red-footed Falcons by habitat type

1. táblázat $A$ kék vércsék aktív vadászatainak élőhely típusonként becsült sikeressége

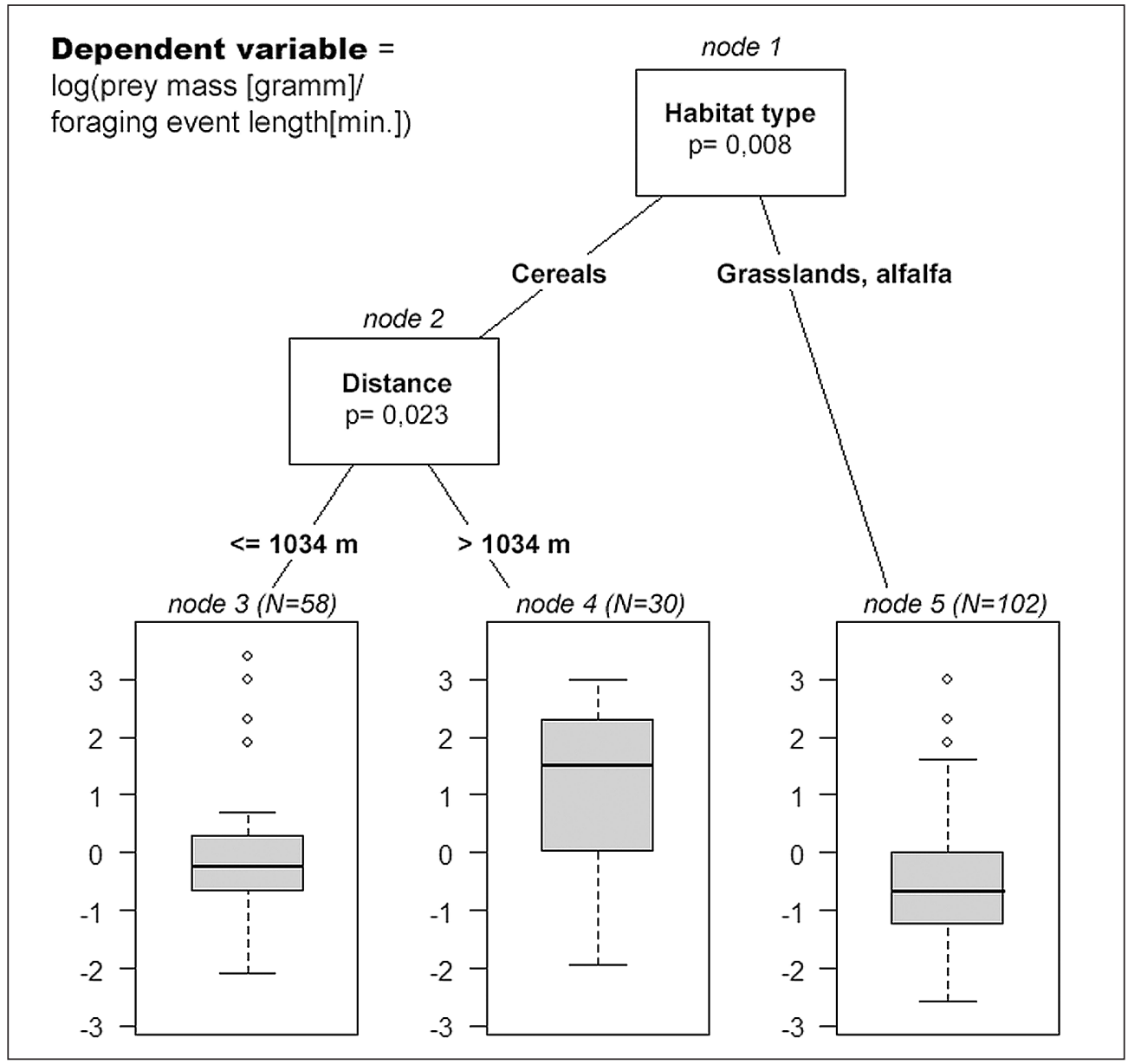

Figure 1. Factors affecting the success (biomass (gramm)/minute) of active hunting events of Redfooted Falcons

1.ábra A kék vércsék aktív vadászatainak sikerességét (biomassza (gramm)/ perc) befolyásoló változók döntési fája 


\section{Dependent variable $=\log (\text { prey biomass }[\mathrm{gramm}] / \text { foraging event lenght }[\mathrm{min}])^{\star}$}

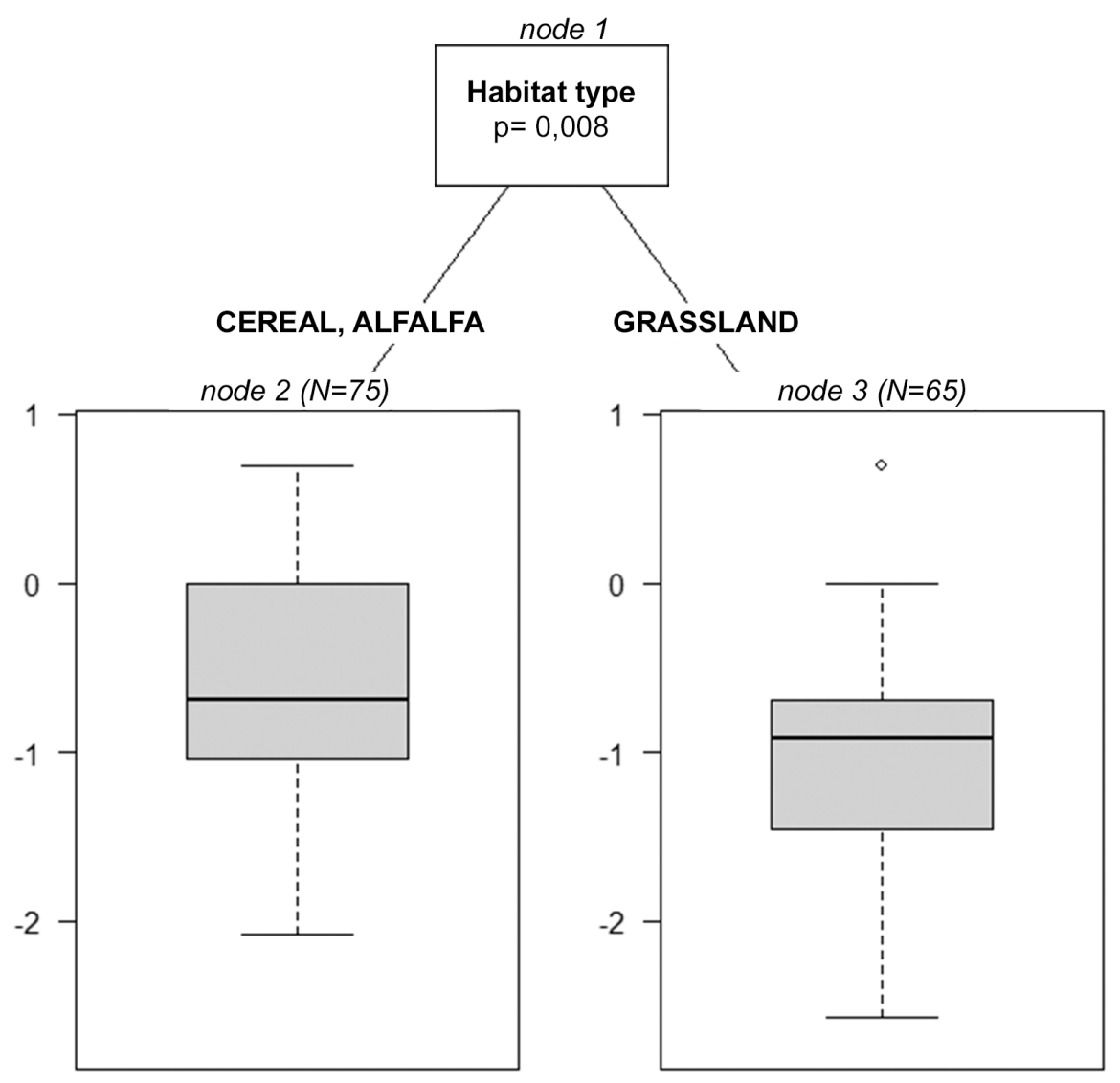

* only insect prey captures

Figure 2. Factors affecting the success (biomass (grams)/minute) of active insect hunts of Red-footed Falcons

2. ábra A kék vércsék rovar zsákmánnyal végződő vadászatainak sikerességét (biomassza (gramm)/ perc) befolyásoló változók döntési fája

1 (min.: 0.125; max.: 22), in grasslands and in alfalfa fields this value is 0.5 (min.: 0.08 ; max.: $20 ; \mathrm{n}=102)$.

The huntings performed in cereal fields can be further grouped into two significantly different groups $(\mathrm{p}=0.023)$ depending on how far they happened from the colony (Figure 1). In the case of hunts in the near group (within $1 \mathrm{~km})(\mathrm{n}=58)$ the average of biomass per unit time (grams/minute) is 0.75 (min.: 0.125 ; max.: 22), while in the case of huntings performed in the average distance category $(\min .: \sim 1 \mathrm{~km})(\mathrm{n}=30)$ this value was 4.5 (min.: 0.14; max.: 20). The reason for this great difference is that in the distant cereal fields 2 out of 3 huntings resulted in verteb- 


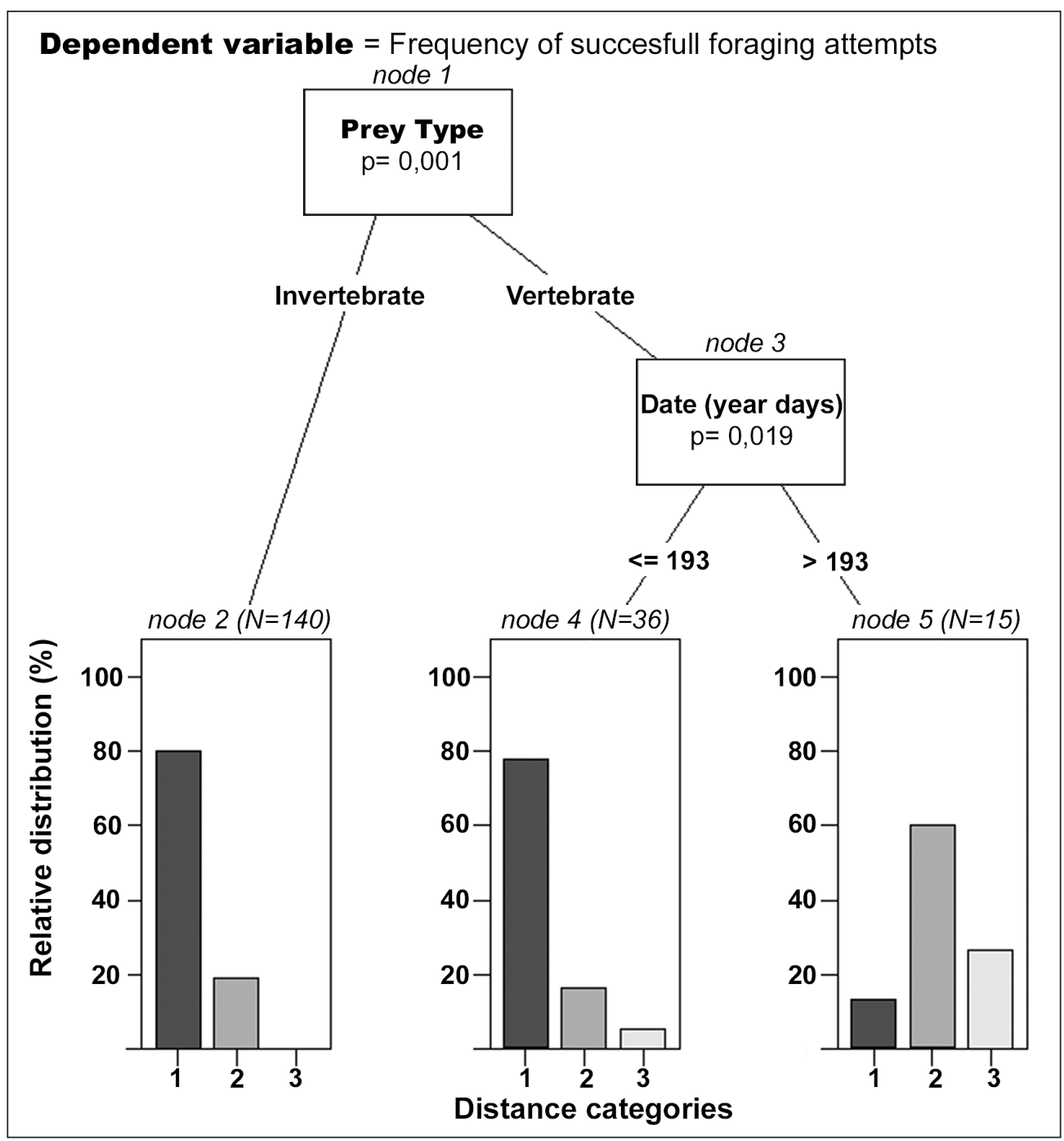

Figure 3. Decision tree on the temporal and spatial pattern of successful Red-footed Falcon hunts (distance categories: $1=$ distance $<1 \mathrm{~km}$ from the nest; $2=1-2.5 \mathrm{~km}$ from the nest; $3=$ more faraway than $2.5 \mathrm{~km}$ from the nest)

3.ábra Döntési fa a kék vércse vadászatok sikerességének tér- és időbeli függésére (távolság kategóriák: 1: < 1 km-re a fészektől, 2: 1-2,5 km-re a fészektől, 3 >2,5 km-re a fészektől)

rate prey items, $(n=20)$, while in the case of hunts closer to the colony only in $17 \%(\mathrm{n}=10)$ of the cases were vertebrates caught.

The necessary time to capture vertebrate prey in grasslands and alfalfa fields was 3 minutes, while in corn fields only 2 minutes. However the estimated success of Red- footed Falcon hunts in the different habitat types not always depends on the chance to catch the much larger vertebrate prey items. If we analyse the successful insect hunts $(n=140)$ with decision trees, the difference among habitat types is significant again $(\mathrm{p}=0.007)$ (Figure 2). 


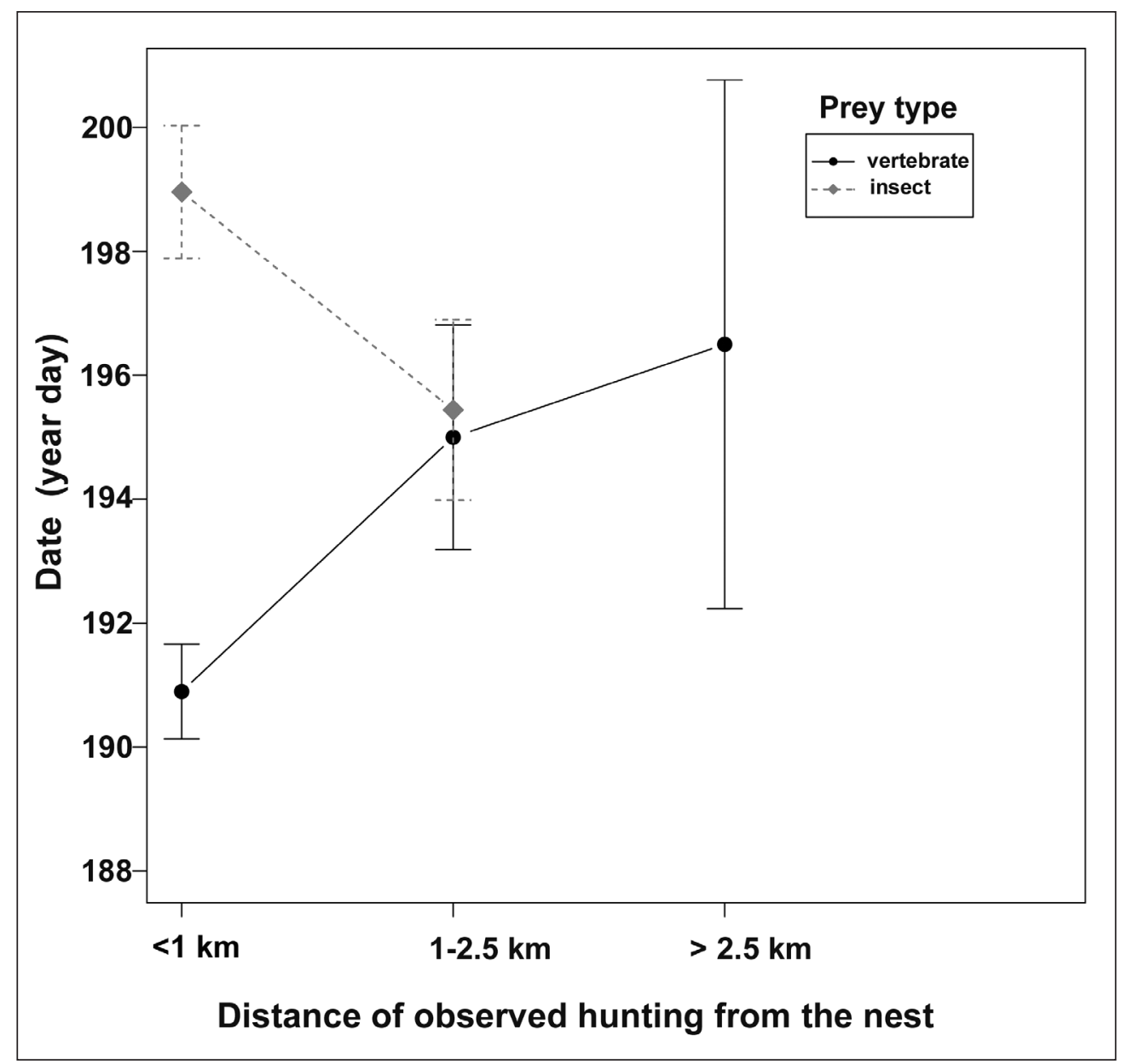

Figure 4. Temporal and spatial pattern of the relative frequency of successful hunts of Red-footed Falcons

4. ábra A kék vércse sikeres vadászatai relatív gyakoriságának tér- és időbeli függése

In the case of insect hunts the average of biomass per unit time (grams/minute) is 0.5 (min.: 0.125 ; max.: 2) in alfalfa and cereal plots $(\mathrm{N}=75)$ regardless of distance, while in grasslands $(n=65)$ the average was 0.4 (min.: 0.08; max.: 2). These differences practically mean that on average a successful insect hunt lasts for 4 minutes in grasslands, 2 minutes in alfalfa fields, while 3 minutes in cereal fields.

We also analysed the temporal and spatial pattern of successful hunting events.
Dependent variable was the frequency of successful hunts, independent grouping variables were: prey-type, continuous and category distance parameters, and day of year (Figure 3-4).

The vast majority of hunts were performed less than 2.5 kilometres from the colony, and what is more important, there is a significant difference between the spatial pattern of insect hunts and vertebrate hunts $(\mathrm{p}=0.001)$. About $80 \%$ of all insect hunts $(n=140)$ were recorded closer than $1 \mathrm{~km}$ from the nest, 
and the remaining $20 \%$ were recorded within $2.5 \mathrm{kms}$. The observed successful vertebrate hunts $(n=51)$ showed a markedly different distribution: $60 \%$ were performed in areas located near to the nest (within $1 \mathrm{~km}$ ), a further $30 \%$ were closer than $2.5 \mathrm{kms}$, and the remaining $10 \%$ were performed in distant areas (more than $2.5 \mathrm{kms}$ ).

The second level of the decision tree shows the temporal pattern of vertebrate hunts, and two significantly different $(\mathrm{p}=0.019)$ groups can be differentiated (Figure 3). As the year advances the ratio of vertebrate hunts changes in the closer hunting plots. Earlier Red-footed Falcon catches predominantly vertebrate prey items in the vicinity of the colony (Figure 4). The observed hunts shifted to more distant locations, as the breeding season advance, and insects were also caught later on. In the latest phase of observations the importance of insects caught near the nest increased. The observed change in hunting pattern was independent from the nesting phase of the individual, it was determined by the calendar date.

\section{Discussion}

\section{A bird in the hand is worth two in the bush?}

Colonially breeding bird species as Redfooted Falcon are mostly characterized by central place foraging and feeding on spatially aggregated food resources (Orians \& Perason 1979). In case of the falcons - that are unable to stock the prey - this means that after every successful hunt the food item has to be carried back to the nest. The nutritional value of the given prey item, its digestibility, searching and handling time, catching and transporting prey all counts when we try to calculate the net energy gain of a hunt.

The nutritional value of insects calculated for dry weight is 20-25 kJ/g (Bell 1990), while that of Field Voles varies largely with their size, but always more than 25 $\mathrm{kJ} / \mathrm{g}$ (Sawicka-Kapusta 1970). The nutritional value of the two main prey types of Red-footed Falcons therefore show a similar magnitude per unit of weight. The digestibility of the two prey type is not known, but both of them contain quite large quantity of nondigestible remains that can be found in the pellets of the falcons (mammals: bones and fur, while insects: chitin).

The handling time of insects is evidently smaller than that of mammals, especially in case of smaller nestlings, when parents have to feed each offspring carefully. However in the second half of the chick rearing period investigated in our study the chicks either swallow the prey as a whole, or the female tears it apart for them. Hence in the case of male Red-footed Falcons we do not have to take into count the handling time differences of insect and mammal prey.

The transport of an insect to the nest costs less energy than that of relatively large vertebrate prey. Falcons are excellent flyers, and compared to the very high cost of finding and catching prey, the cost of the transport has probably much less importance (Kvist et al. 2001, Nudds \& Bryant 2002).

To sum up besides the size of the prey item and the effectiveness of its capture (these parameters together form hunting success parameter of our analysis), the time invested into finding the right hunting grounds may be the other major component affecting the profitability of each hunt. 


\section{Hunting success in different habitat types}

Although the estimated biomass of mammals is considerably higher then, that of insects, in the appropriate hunting area the average time needed to catch them can be even shorter. According to our observations the active hunt for mammal prey depending on the habitat type takes 2-3 minutes on average, while that of insects 2-4 minutes. With the same investment the catching of mammals is probably much more profitable for Red-footed Falcons. If the energy expenditure is equal probably catching mammal prey is more profitable for Red-footed Falcons, than that of insects. Consequently the net energy gain for a small insect carried back to the nest is diminishing as the distance from the place of catching prey to the nest increases (diminishing return is an inverse function of distance), while for a larger mammal the transport cost cannot fully burn up the energy gain.

Catching of vertebrate prey (predominantly Field Voles) was fastest in cereal stubble fields then in other habitat types, it was a very important factor in the decision of choosing hunting sites, and hence largely affected the spatial pattern of space use. Another indirect indicator of the importance of mammal prey is that in Field Vole gradation years the breeding success of Red-footed Falcons is significantly higher than in other years (Palatitz et al. 2010).

Moreover hunts resulted in insect catching on alfalfa and cereal stubble fields proved to be more successful than those carried out on grasslands. In the study period on our study area considerable proportion of landowners applied for agri-environmental subsidies (Ángyán et al. 2003), and the nature protection oriented management by the
National Park Directorate ensured that in all the studied habitat types nature conscious biodiversity oriented management regimes were applied. Although there were some assessments in order to monitor the yearly change of food resources on the study area (Böde 2008, Juhász 2008, Szövényi 2015), we do not have strong evidence to assess the difference of food availability on the habitat types. The importance of grasslands and alfalfa plots in conserving biodiversity is widely accepted. Probably these periodically stable habitats provide favourable conditions for the Orthoptera species and Field Voles that form the bulk of food carried for the young of Red-footed Falcons (Báldi \& Kisbenedek 1997, Böde 2008). However these prey groups are prone to large population fluctuations and during gradation might appear in virtually any habitat types that provide minimal conditions for them (Delattre et al. 1996, Michel et al. 2006). Therefore it is probable that they were present in high quantity and density in many habitat types, when their gradation was confirmed in our study area. Our field observations and the results of trapping also confirm this assumption.

The accessibility of prey has differed substantially among the habitat types. In the study area the mowing of grasslands usually starts on the $15^{\text {th }}$ of June. The first mowing of alfalfa fields continuously happened from the second half of May, while the harvest of cereals started in the last week of June and went on for about a month (personal observation). This meant that in the study period the grasslands mowed earlier in the season were mostly covered with growing vegetation. To a lesser degree where mowing was not carried out yet, or the plot was grazed a mosaic-like various vegetation height prevailed. The alfalfa fields that were mowed 
earlier than grasslands showed various vegetation height depending on the date of mowing, the general characteristics of the plot and the applied mowing technique. The harvest of corn fields was performed parallel with our observation period, so during the studies we could find all phases of wheat and corn fields from the not yet cut plots through the stubble fields to the already tilled fields. Two characteristics of the cereal fields were very different from grasslands and alfalfa fields: they became open for birds during the study period, and the mowed fields were covered with very short vegetation. According to our data all the observed Red-footed Falcon hunts in cereal fields were performed in stubble fields, often on those fields that were tilled right after harvest. Probably the agricultural activities significantly improved the chance of successful hunts. The lack of vegetation cover and the disturbed burrows of voles could contribute largely to the observed hunting success of falcons for this prey type on stubbles. Therefore low vegetation cover and hence the good detectability of vertebrate prey on stubble cereal fields might have led to higher hunting success in these fields than in grasslands or alfalfa fields respectively.

Our earlier experiments showed that Orthopterans emigrate from mowed fields and try to find cover in the adjacent edge habitats (Juhász 2008). Territorial small mammals probably react differently to mowing. The earlier mowed, and then re-grown alfalfa fields provided mosaic-like, massive green mass for insects (Bretagnolle et al. 2011). The abundance of Orthoptera species could be higher than in other habitat types. Probably this explains why Red-footed Falcons captured insects more efficiently in the sparsely vegetated patches and edges of alfalfa fields.
The phenomenon described her is not unique, Lesser Kestrels in Spain mainly hunt at the edges of arable fields and set aside fields, and the extensively cultivated cereal fields (Bustamante 1997, Franco \& Sutherland 2004, De Frutos et al. 2009). Lesser Kestrels also catch prey faster in ploughed fields than in natural grasslands or in the edges of vegetation (Rodriguez et al. 2006), and the hunting success is closely related to the used agrotechnics (Ursua et al. 2005, Catry et al. 2011).

Despite our results in the given period and study site it would be a mistake to underestimate the importance of natural habitats. The role of grasslands in the choice of nesting sites is not a mere coincidence (Fehérvári et al. 2009, Fehérvári et al. 2012), on the other hand in the period prior chick rearing, or in years with different food availability (for example when Field Vole density is lower), probably their importance is relatively more significant.

\section{Spatial and temporal patterns of hunt- ing success}

We observed that Red-footed Falcons effectively hunted for vertebrate prey at the close proximity of the nest sites at the early phase of our studies. After a few days they started to hunt at more faraway plots, and we could only observe successful vertebrate hunts $1-2.5 \mathrm{kms}$ from the nest, or even more far away.

In colonially breeding birds the competition for food increases as the number of breeding birds increases (Furness \& Birkhead 1984, Brown \& Brown 2001, Ainley et al. 2004). Unfortunately we have no data whether the relative larger predation pressure near the colonies, where hunting could be performed with lover travelling cost, is 
reducing either the availability or abundance of the prey types. In Lesser Kestrels a similar phenomenon was described, when the decrease in prey density influenced the fitness of the birds in a measurable fashion (Bonal \& Aparicio 2008).

Some prey taxa of the falcons, for example the small rodents that exhibit complex behaviour can adapt to the elevated predation pressure (Korpimäki et al. 1996). Their behaviour changes: the daily activity decreases and night activity increases, and hence the chance of getting caught by day-time predators, as birds of preys is lessened. We assume that due to strong predation pressure near the colony the availability of voles changed, and hence as the season advanced Red-footed Falcons were not able to deplete these resources effectively.

The shift to more far away fields to hunt rodents, and the appearance of insect hunting coincided in time. In the mid-term of our observations Red-footed Falcons started to hunt insects in fields nearer than $2.5 \mathrm{kms}$ to the colonies. Then after in the third term of the chick feeding, insect hunts closer than 1 $\mathrm{km}$ to the nest site were performed the most frequently.

The spatial and temporal pattern of the successful hunts for the two main prey type showed an opposing trend. To hunt mammal prey items offering higher net energy gain the birds went more and more away from the colonies, while they were hunting for insects nearer and nearer as calendar date advanced. In some aspects hotly debated (Pyke 1984, Ydenberg et al. 1994) however optimal foraging theory (Stephens \& Krebs 1986) is still often used as a theoretical framework for studies on animal foraging. It predicts that the more distant a feeding area is, the higher net energy intake rate it must offer, otherwise its use is not profit- able. Above a certain distance threshold it is not worth investing in searching a more profitable hunting area (Fauchald 2009). It is possible that the nearer foraging areas, rich in insects, offering lower energy intake but costing less in terms of travel were chosen for this reason by falcons in our study.

It is very difficult to assess at what food availability level which distance will be still efficient to hunt for food to feed the offsprings (Rodriguez et al. 2006). We observed that there was only a single case from the 52 successful mammal hunts $(1.9 \%)$, when the prey was not carried back to the nest. But we often observed that the most energy-rich part, the brain was removed and eaten frequently by the hunting bird, so a headless carcass was passed on to the female or chicks. From the insect hunts $(n=140)$ in $36.4 \%$ the observed bird consumed the caught insect itself, and continued hunting.

From our data we can not tell, whether in vole gradation years Red-footed Falcons actively search for rodent-rich plots in their home range, where they can very efficiently hunt? Probably in these periods insects only serve as a supplementary food resource regarding the total biomass of the chick diet. The percentage of insects in the diet is always higher than that of mammals', even in the periods when the later constitute the primary prey choice (Böde 2008). Both the breeding success of Red-footed Falcons and the condition of chicks suggest that Field Voles are the corner stone of hunting in gradation years (Palatitz et al. 2010).

Probably it is not easy to find good Field Vole yielding plots, and as they become depleted very fast, more and more faraway plots needs to be visited. The feeding ecology of aggregated predators long been studied by ecologists. In larger colonies infor- 
mation from other birds could be obtained on potential feeding grounds, and hence larger areas can be profitably exploited (Rafacz \& Templeton 2003). This suggests that the home range of Red-footed Falcons nesting at larger colonies was larger than that of birds nesting in smaller colonies or breeding solitarily (Palatitz et al. 2011). Feeding in groups is more efficient for those animal food sources that are either patchy, or very short-lived because of depletion due to predation or emigration (Jacob \& Brown 2000). At the same time competition is stronger at colonies (Brown \& Brown 2001). If due to low food availability the time necessary to find food increases (Fauchald 2009) birds breeding at colonies the formerly listed advantages might easily turn into disadvantages. As in Red-footed Falcons both solitary and colonial breeding coexists in the same habitat (Kotymán et al. 2015) for a long evolutionary time, their feeding strategies are expected to be even more refined (Barta \& Giraldeau 2001), and therefore the analyses of their feeding behaviour by mechanistic modelling (Moorcroft et al. 1999) will be even more intriguing.

When applying our results for management and protection it is worth keeping in mind, that the results were obtained in an extremely food-rich breeding season (Field Vole gradation year), at a single Red-footed Falcon breeding habitat. We hope that the zonal partition of our feeding areas will form a good basis when planning more complex research projects as in Lesser Kestrel (Franco \& Sutherland 2004, Catry et al. 2011) or for the planning of nature protec- tion oriented management of agro-ecosystems (Young et al. 2005, Kleijn et al. 2009).

Our results highlight the fact that even for such characteristic grassland specialist birds as Red-footed Falcons the prey sources offered by arable lands might be temporarily important. If we utilise this knowledge in the management of habitats, it might facilitate the harmonisation of the needs of different species, and it might enlarge the scope, spatial dimension and efficiency of habitat management.

\section{Acknowledgements}

We express our gratitude to Tibor István Fuisz for translating the text and for his comments on the earlier version of the manuscript.

We also thank for creating the map database and carrying out basic research: Dóra Neidert, Dániel Kristóf, Gergely Szövényi, Zoltán Soltész, Mária Kiss, Károly Erdélyi, Anikó Kovács-Hostyánszki, Renata Kopena and our diligent undergraduate students who all contributed to this manuscript; Ágnes Böde, Tibor Juhász, Dóra Rideg, Anett Horváth, Zsaklin Széles, Bence Lázár, Imre Sándor Piross. We thank Peter Fehérvári for his help in the statistical analyses.

This research was supported by LIFE Nature projects (LIFE05/NAT/HU/000122, LIFE11/NAT/HU/000926), and a PhD thesis was written on this theme under the supervision of Dr. Sándor Csányi at the Institute of Wildlife Conservation, Szent István University, Gödöllő, Hungary in 2012. 


\section{References}

Ainley, D. G., Ribic, C. A., Ballard, G., Heath, S., Gaffney, I., Karl, B. J., Barton, K. J., Wilson, P. R. \& Webb, S. 2004. Geographic structure of Adélie Penguin populations: overlap in colony-specific foraging areas. - Ecological Monographs 74(1): 159-178. DOI: 10.1890/02-4073

Ángyán, J., Tardy, J. \& Vajnáné Madarassy, A. 2003. Védett és érzékeny természeti területek mezőgazdálkodásának alapjai [Agriculture for environmentally protected and sensitive areas]. - Mezőgazda Kiadó, Budapest, pp. 522 (in Hungarian)

Báldi, A. \& Kisbenedek, T. 1997. Orthopteran assemblages as indicators of grassland naturalness in Hungary. - Agriculture, Ecosystems \& Environment 66(2): 121-129.

Barta, Z. \& Giraldeau, L-A. 2001. Breeding colonies as information centers: a reappraisal of information-based hypotheses using the producerscrounger game. - Behavioral Ecology 2(12): 121-127. DOI: 10.1093/beheco/12.2.121

Bell, G. P. 1990. Birds and mammals on an insect diet: a primer on diet composition analysis in relation to ecological energetics. - In: Morrison, M. L., Ralph, C. J., Verner, J. \& Jehl, J. R. Jr. (eds.) Avian foraging: theory, methodology and applications - Cooper Ornithological Society Available at: http://www.researchgate.net/profile/Gary_Bell2/ publication/262014380_Birds_and_mammals_ on_an_insect_diet_a_primer_on_diet_composition_analysis_in_relation_to_ecological_energetics/links $/ \overline{00} 4 \overline{6} 35367 \mathrm{~b} \overline{7} \mathrm{dd} \overline{5} 9 \mathrm{e} 400000000$.pdf [Accessed January 29, 2015].

Böde, Á. 2008. A kék vércse (Falco vespertinus) táplálkozásbiológiája [Prey composition of Red-footed Falcon diet]. - MSc thesis, Nyugat-Magyarországi Egyetem (NYME), Sopron, pp. 42

Bonal, R. \& Aparicio, J. M. 2008. Evidence of prey depletion around Lesser Kestrel Falco naumanni colonies and its short term negative consequences. - Journal of Avian Biology 39(2): 189-197. DOI: 10.1111/j.2008.0908-8857.04125.x

Breiman, L., Friedman, J., Stone, C. J. \& Olshen, R. A. 1984. Classification and regression trees. - Boca Ratón Florida, USA, Chapman \& Hall/CRC, pp. 358

Bretagnolle, V., Villers, A., Denonfoux, L., Cornulier, T., Inchausti, P. \& Badenhausser, I. 2011. Rapid recovery of a depleted population of Little Bustards Tetrax tetrax following provision of alfalfa through an agri-environment scheme. - Ibis 153: 4-13. DOI: 10.1111/j.1474-919X.2010.01092.x
Brown, C. \& Brown, M. 2001. Avian Coloniality. In: Nolan, V. Jr. \& Thompson, C. (eds.) Current Ornithology. - Springer US, pp. 1-82. DOI: 10.1007/978-1-4615-1211-0_1.

Bub, H. 1991. Bird trapping and bird banding: a handbook for trapping methods all over the world. Cornell University Press, New York, pp. 330

Bustamante, J. 1997. Predictive models for Lesser Kestrel Falco naumanni distribution, abundance and extinction in southern Spain. - Biological Conservation 80(2): 153-160.

Calenge, C. 2006. The package 'adehabitat' for the R software: a tool for the analysis of space and habitat use by animals. - Ecological Modelling 197: 516-519. DOI: 10.1016/j.ecolmodel.2006.03.017

Catry, I., Amano, T., Franco, A. M. A. \& Sutherland, W. J. 2011. Influence of spatial and temporal dynamics of agricultural practices on the Lesser Kestrel. - Journal of Applied Ecology 49(1): 99108. DOI: 10.1111/j.1365-2664.2011.02071.x

Cramp, S. \& Simmons, K. E. L. 1980. The birds of the western Palearctic, Vol. 2. - Oxford University Press, Oxford, pp. 696

Delattre, P., Giraudoux, P., Baudry, J., Queré, J. P. \& Fichet, E. 1996. Effect of landscape structure on Common Vole (Microtus arvalis) distribution and abundance at several space scales. - Landscape Ecology 11(5): 279-288.

Fauchald, P. 2009. Spatial interaction between seabirds and prey: review and synthesis. - Marine Ecology Progress Series 391: 139-151. DOI: 10.3354/meps07818

Fehérvári, P., Solt, S., Palatitz, P., Barna, K., Ágoston, A., Gergely, J. \& Harnos, A. 2012. Allocating active conservation measures using species distribution models: a case study of Red-footed Falcon breeding site management in the Carpathian Basin. - Animal Conservation 15(6): 648-657. DOI: 10.1111/j.1469-1795.2012.00559.x

Fehérvári, P., Neidert, D., Solt, S., Kotymán, L., Szövényi, G., Soltész, Z. \& Palatitz, P. 2007. Kék vércse élőhelypreferencia vizsgálat - egy tesztév eredményei [Red-footed Falcon habitat preference analysis - results of a test year]. - Heliaca 3: 51-59.

Fehérvári, P., Harnos, A., Neidert, D., Solt, S. \& Palatitz, P. 2009. Modelling habitat selection of the Red-footed Falcon (Falco vespertinus): a possible explanation of recent changes in breeding range within Hungary. - Applied Ecology and Environmental Research 7(1): 59-69.

Franco, A. \& Sutherland, W. J. 2004. Modelling the foraging habitat selection of Lesser Kestrels: 
conservation implications of European agricultural policies. - Biological Conservation 120(1): 6374. DOI: 10.1016/j.biocon.2004.01.026

De Frutos, A., Olea, P. P., Mateo-Tomás, P. \& Purroy, F. J. 2009. The role of fallow in habitat use by the Lesser Kestrel during the post-fledging period: inferring potential conservation implications from the abolition of obligatory set-aside. - European Journal of Wildlife Research 56(4): 503-511. DOI: 10.1007/s10344-009-0338-4

Fülöp, Z. \& Szlivka, L. 1988. Contribution to the food biology of the Red-footed Falcon (Falco vespertinus). - Aquila 25: 174-181.

Furness, R. W. \& Birkhead, T. R. 1984. Seabird colony distributions suggest competition for food supplies during the breeding season. - Nature 311: 655-656.

Haraszthy, L., Rékási, J. \& Bagyura, J. 1994. Food of the Red-footed Falcon in the breeding period. Aquila 101: 93-110.

Haraszthy, L. (ed.) 1998. Magyarország madarai [Birds of Hungary]. - Mezőgazda Kiadó, Budapest, pp. 433 (in Hungarian)

Horváth, L. 1963. A kékvércse (Falco vespertinus L.) és a kis örgébics (Lanius minor Gm.) élettörténetének összehasonlító vizsgálata I. A tavaszi érkezéstől a fiókák kikeléséig [Comparing life history of Red-footed Falcons and Lesser Grey Shrikes I. From spring arrival to hatching]. - Vertebrata Hungarica 5(1-2): 69-121. (in Hungarian)

Jacob, J. \& Brown, J. S. 2000. Microhabitat use, giving-up densities and temporal activity as shortand long-term anti-predator behaviors in Common Voles. - Oikos 91(1): 131-138. DOI: 10.1034/j.1600-0706.2000.910112.x

Juhász, T. 2008. A kaszálás hatása a kék vércse (Falco vespertinus) fóbb zsákmány csoportjaira [The effect of mowing on the main prey items of Red-footed Falcons]. - MSc thesis, Szent István University, Gödöllő, pp. 51

Keve, A. \& Szijj, J. 1957. Distribution, biologie et alimentation du Faucon kobez Falco vespertinus L. en Hongrie [Distribution, biology and allimentation of Red-footed Falcons in Hungary]. - Alauda 25(1): 1-23. (in French)

Kleijn, D., Kohler, F., Báldi, A., Batáry, P., Concepción, E. D., Clough, Y., Díaz, M., Gabriel, D., Holzschuh, A., Knop, E., Kovács, A., Marshall, E. J. P., Tscharntke, T. \& Verhulst, J. 2009. On the relationship between farmland biodiversity and land-use intensity in Europe. - Proceedings of the Royal Society B: Biological Sciences 276: 903909. DOI: 10.1098/rspb.2008.1509

Korpimäki, E., Koivunen, V. \& Hakkarainen, H. 1996. Microhabitat use and behavior of voles under
Weasel and raptor predation risk: predator facilitation? - Behavioral Ecology 7(1): 30-34.

Kotymán, L., Solt, Sz., Horváth, É., Palatitz, P. \& Fehérvári, P. 2015. Demography, breeding success and effects of nest type in artificial colonies of Red-footed Falcons and allies. - Ornis Hungarica 23(1): 1-21. DOI: 10.1515/orhu-2015-0001

Krebs, J. R., MacRoberts, M. H. \& Cullen, J. M. 1972. Flocking and feeding in the Great Tit Parus major - an experimental study. - Ibis 114(4): 507-530. DOI: 10.1111/j.1474-919X.1972.tb00852.x

Kristóf, D., Neidert, D., Nagy, Z. \& Pintér, K. 2007. Integrating MODIS Surface Reflectance Products into the Processing of Medium and High-resolution Satellite Images: Difficulties and Solutions through Two Hungarian Case Studies. In: Analysis of Multi-temporal Remote Sensing Images. MultiTemp. International Workshop on the Analysis of Multi-temporal Remote Sensing Images. IEEE, pp. 1-6. DOI: 10.1109/MULTITEMP.2007.4293059

Kvist, A., Lindström, Å., Green, M., Piersma, T. \& Visser, G. H. 2001. Carrying large fuel loads during sustained bird flight is cheaper than expected. - Nature 413(6857): 730-732. DOI: 10.1038/35099556;

Masman, D. \& Klaasen, M. 1987. Energy expenditure during free flight in trained and free-living Eurasian Kestrels (Falco tinnunculus). - The Auk 104: 603-616.

Michel, N., Burel, F. \& Butet, A. 2006. How does landscape use influence small mammal diversity, abundance and biomass in hedgerow networks of farming landscapes? - Acta Oecologica 30(1): 11-20. DOI: 10.1016/j.actao.2005.12.006

Moorcroft, P., Lewis, M. \& Crabtree, R. 1999. Home range analysis using a mechanistic home range model. - Ecology 80(5): 1656-1665. DOI: 10.2307/176554

Nudds, R. L. \& Bryant, D. M. 2002. Consequences of load carrying by birds during short flights are found to be behavioral and not energetic. - American Journal of Physiology-Regulatory, Integrative and Comparative Physiology 283(1): R249-R256. DOI: 10.1152/ajpregu.00409.2001

Orians, G. H. \& Perason, N. E. 1979. On the theory of central place foraging. - In: Horn, D. J., Stairs, E. T. \& Mitchell, R. D. (eds.) Analysis of ecological systems. - Ohio State University Press, Columbus, pp. 155-177.

Palatitz, P. 2012. A kék vércse (Falco vespertinus) védelmének tudományos megalapozása [Scientific basis of Red-footed Falcon conservation]. - PhD thesis, Szent István University, Gödöllö, pp. 128 
Palatitz, P., Solt, S., Fehérvári, P., Gergely, J., Ágoston, A. \& Barna, K. 2010. Az MME Kékvércse-védelmi Munkacsoport beszámolója [Annual report of the MME/BirdLife Hungary Red-footed Falcon Conservation Working Group]. - Heliaca 1: 1421. (in Hungarian)

Palatitz, P., Fehérvári, P., Solt, S., Kotymán, L., Neidlert, D. \& Harnos, A. 2011. Exploratory analyses of foraging habitat selection of the Redfooted Falcon (Falco vespertinus). - Acta Zoologica Academiae Scientiarum Hungaricae 57(3): 255-268.

Pennycuick, C. J. 2008. Modelling the flying bird Bristol. - Academic Press, UK., pp. 496

Purger, J. J. 1996. Numbers and distribution of Red-footed Falcon (Falco vespertinus) nests in Voivodina (Northern Serbia). - Journal of Raptor Research 30(3): 165-168.

Purger, J. J. 1997. Accidental death of adult Red-footed Falcons Falco vespertinus and its effect on breeding success. - Vogelwelt 118: 325-327.

Purger, J. J. 1998. Diet of Red-footed Falcon Falco vespertinus nestlings from hatching to fledging. Ornis Fennica 75(4): 185-191.

Pyke, G. H. 1984. Optimal foraging theory: a critical review. - Annual Review of Ecology and Systematics 15: 523-575.

Quantum GIS Development Team 2011. Quantum GIS Geographic Information System, Open Source Geospatial Foundation Project. - Available at: http://qgis.osgeo.org.

Rafacz, M. \& Templeton, J. J. 2003. Environmental unpredictability and the value of social information for foraging Starlings. - Ethology 109(12): 951960. DOI: 10.1046/j.0179-1613.2003.00935.x.

R Development Core Team 2011. R: A language and environment for statistical computing. - Vienna, Austria: R Foundation for Statistical Computing. Available at: http://www.R-project.org.

Richner, H. \& Heeb, P. 1996. Communal life: honest signaling and the recruitment center hypothesis. Behavioral Ecology 7(1): 115-119.

Rodriguez, C., Johst, K. \& Bustamante, J. 2006. How do crop types influence breeding success in Lesser Kestrels through prey quality and availability? A modelling approach. - Journal of Applied Ecology 43(3): 587-597. DOI: 10.1111/j.13652664.2006.01152.x.
Sawicka-Kapusta, K. 1970. Changes in the gross body composition and the caloric value of the Common Voles during their postnatal development. - Acta Theriologica 15(4): 67-79.

Szövényi, G. 2015. Orthopteran insects as potential and preferred preys of the Red-footed Falcon (Falco vespertinus) in Hungary. - Ornis Hungarica 23(1): 48-57. DOI: 10.1515/orhu-1015-0004

Stephens, D. W. \& Krebs, J. R. 1986. Foraging theory. - Princeton University Press, New Jersey, USA, pp. 249

Tella, J. L., Forero, M. G., Hiraldo, F. \& Donázar, J. A. 1998. Conflicts between Lesser Kestrel conservation and European agricultural policies as identified by habitat use analyses. - Conservation Biology 12(3): 593-604. DOI: 10.1111/j.15231739.1998.96288.x.

Ursua, E., Serrano, D. \& Tella, J. L. 2005. Does land irrigation actually reduce foraging habitat for breeding Lesser Kestrels? The role of crop types. - Biological Conservation 122(4): 643-648. DOI: 10.1016/j.biocon.2004.10.002

Ward, P. \& Zahavi, A. 1973. The importance of certain assemblages of birds as 'information-centres' for food-finding. - Ibis 115(4): 517-534.

Weimerskirch, H., Bertrand, S., Silva, J., Marques, J. C. \& Goya, E. 2010. Use of social information in seabirds: Compass rafts indicate the heading of food patches. - PLoS ONE 5(3): e9928. DOI: 10.1371/journal.pone.0009928

Wright, J., Stone, R. E. \& Brown, N. 2003. Communal roosts as structured information centres in the Raven, Corvus corax. - Journal of Animal Ecology 72(6): 1003-1014. DOI: 10.1046/j.13652656.2003.00771.x

Ydenberg, R. C., Welham, C. V. J., Schmid-Hempel, P. \& Beauchamp, G. 1994. Time and energy constraints and the relationships between currencies in foraging theory. - Behavioral Ecology 5(1): 28-34. DOI: 10.1093/beheco/5.1.28

Young, J., Watt, A., Nowicki, P., Alard, D., Clitherow, J., Henles, K., Johnson, R., Laczko, E., McCracken, D., Matouch, S., Niemela, J. \& Richards, C. 2005. Towards sustainable land use: identifying and managing the conflicts between human activities and biodiversity conservation in Europe. - Biodiversity and Conservation 14: 1641-1661. DOI: 10.1007/s10531-004-0536-z 